\title{
NÁVŠTEVNOSŤ ČESKA OBČANMI SLOVENSKA A JEJ PRIESTOROVÉ DIMENZIE
}

\author{
Alfred Krogmann, Magdaléna Nemčíková, Daša Oremusová, Lucia Šolcová, \\ Zuzana Dvořáková Líšková
}

\begin{abstract}
The aim of the article is to evaluate the importance of Slovakia for tourism visitation in the Czechia. Based on sources available from the Czech Statistical Office, it can be said, that Slovakia is an important market for Czech tourism in terms of visitation and number of overnight stays. This fact positively affects a missing language barrier, as well as their geographical proximity. This is also the reason for shorter stays of Slovak citizens in the Czechia, but this is replaced by the frequency of arrivals. In terms of spatial distribution, the world dominates Prague and then the border regions headed by the Jihomoravsky region. On the contrary, the most recent interest of Slovaks in Czechia records the regions peripherally due to their position towards Slovakia.
\end{abstract}

Keywords: the number of guests in accommodation establishments, the number of overnight stays, average length of stay, spatial layout, Slovak visitors

\section{Úvod}

Cestovný ruch ponúka z geografického hl'adiska široký priestor pre štúdium. Jedna z možností vychádza zo samotných definícií cestovného ruchu (napr. Steinecke, 2006, Mariot, 1983, Benthien, 1997 a i.), ktorých spoločnou črtou je zdôrazňovanie procesu premiestňovania osôb z miesta trvalého bydliska do miesta dočasného pobytu za účelom obnovy fyzických a psychických síl. Takýto špecifický druh migrácie môže $\mathrm{v}$ prípade priaznivých podmienok ponúknut' databázu vhodnú pre priestorové zhodnotenie návštevnosti (napr. počet ubytovaných, počet prenocovaní a priemerná dížka pobytu), ktorá je považovaná Fialovou a Nekolným (2017) za jednu zo základných kvantitatívnych vlastností lokality rôznej mierky (štát, región, lokalita). Takéto údaje sú zaujímavé nie len z pohl’adu akademického pričom hovoria o turistickom význame danej lokality, ale aj pre manažment destinácie pri podpore, resp. naopak pri obmedzení turistickej návštevnosti (Bernátová, Vaňová, 2000).

Ciel’om príspevku je zhodnotenie pozície Slovenska ako vysielajúcej krajiny pre Česko. Zároveň sa v d’alšej časti príspevku sústredíme na vývoj návštevnosti, ako aj priestorovú distribúciu slovenských turistov v Česku. 


\section{Teoreticko-metodické východiská}

Návštevnost' patrí $\mathrm{v}$ rámci cestovného ruchu k najvýznamnejším kvantitatívnym vlastnostiam destinácie bez ohladu na mierku, v ktorej pracujeme (Fialová, Nekolný, 2017). Hodnoty návštevnosti (počet ubytovaných turistov, počet prenocovaní a priemerná dížka pobytu) sú primárnymi ukazovatel'mi turistickej atraktivity územia. Návštevnost' je dôležitá aj pri posudzovaní vplyvu cestovného ruchu na životné prostredie a to najmä pri stanovení únosnej kapacity územia (Pásková, 2012). V súčasnej dobe je možné pozorovat' problémy domácich rezidentov s počtom turistov (tzn. s udržaním prijatel'nej miery zatažitel'nosti destinačného prostredia) v niektorých európskych metropolách, ako napr. Barcelona, Dubrovník. Zvýšená návštevnost' lokality (destinácie) zohráva dôležitú úlohu aj v procese turistifikácie. Ide o transformáciu využívania kultúrnej krajiny, kde hybnou silou je práve cestovný ruch. Konkrétne príklady turistifikácie v Česku sú uvedené v prácach Dumbrovskej a Fialovej (2016) ako aj Páskovej (2012).

Údaje potom môžu byt' východiskom pre analýzy cestovného ruchu vo vybranom území na lokálnej úrovni napr. Pachrová, Janoušková (2016) regionálnej úrovni Kasagranda (2013), Kasagranda s Cákocim (2015), na národnej Marciszewska, Studzieniecki, Wanagos (2017), Beresecká, Hudáková, Papcunová (2018), či globálnej úrovni (Šauer, Vystoupil, Krajíčková, 2018). Sú taktiež fundamentom pre uskutočnenie typizácie stredísk cestovného ruchu, ako tomu bolo v prípade prác Kasagrandu, Rajčákovej a Vystoupila (2016), resp. Vystoupila, Kasagrandu a Šauera (2016). Okrem akademického významu sú údaje o návštevnosti $\mathrm{v}$ slovenských podmienkach dôležité z pohladu manažovania a marketingu cestovného ruchu, nakol'ko jednou z podmienok vzniku oblastných organizácií cestovného ruchu je splnenie podmienky minimálneho počtu prenocovaní na území zakladajúcich obcí. V prípade minimálneho počtu členských obcí (5 obcí) je stanovený súčet prenocovaní na hodnotu 50 000. Minimálny počet obcí môže byt' aj nižší, no v tom prípade musí nadobudnút' súhrnný počet prenocovaných hodnotu najmenej 150000 (Zákon č. 91/2010 Z. z.). Celkový význam oblastných organizácií cestovného ruchu je pritom po splnení limitu prenocovaní daný aj možnost'ou každoročne získat' dotácie zo štátneho rozpočtu

V zmysle Fialovej s Nekolným (2017) je potrebné upozornit', že vzhl'adom na celosvetovo šíriacu sa zdiel'anú ekonomiku ( $v$ segmente ubytovania je to Airbnb) dochádza ku skresleniu dát o návštevnosti, nakol'ko štatistiky ubytovaných prostredníctvom platformy Airbnb absentujú.

Z pohl'adu marketingu je možné údaje o návštevnosti využit' pri zostavovaní rebríčkov návštevnosti stredísk, resp. zariadení cestovného ruchu a prostredníctvom nich ovplyvňovat' d’alší výber navštívenej destinácie. 


\section{Štruktúra návštevnosti Česka podl’a krajiny príchodu}

Územie Česka sa zarad’uje v strednej Európe medzi významné a stabilné turistické ciele. V roku 2017 využilo služby ubytovacích zariadení v Česku viac ako 10 mil. turistov (10 160468 osôb). Dominantné postavenie si udržiavajú turisti prichádzajúci z európskych krajín predstavujúci $71,9 \%$ podiel na príchodoch.

$\mathrm{V}$ rámci európskeho trhu na prvých troch pozíciách sa v návštevnosti uplatnil silný susedský efekt. Z Nemecka smerovalo do Česka až 1962582 osôb, čo predstavuje 19,3\% zo všetkých ubytovaných v r. 2017. Na druhej pozícii sú Slováci s počtom $681917(6,7 \%)$ a trojicu uzatvára Pol’sko prostredníctvom 575643 ubytovaných (5,7 \%). Významnou klientelou sú aj turisti z Ruska v počte 548318 (5,4%). Nasledujú turisti Vel'kej Británie (470 106 - 4,6 \%) či Talianska (389 $578-3,8 \%$ ). Prekvapivú a nie príliš významnú pozíciu vykazuje južný sused Česka - Rakúsko v počte 289583 (2,9 \%) ubytovaných. Viac ako dvojpercentný podiel mali aj turisti z Francúzska, Holandska či Španielska (graf 1).

Graf 1: Štruktúra prichádzajúcich turistov do Česka podl'a častí sveta v r. 2017 Graph 1: Figure 1: The structure of incoming tourists to the Czechia by parts of the world in the year 2017

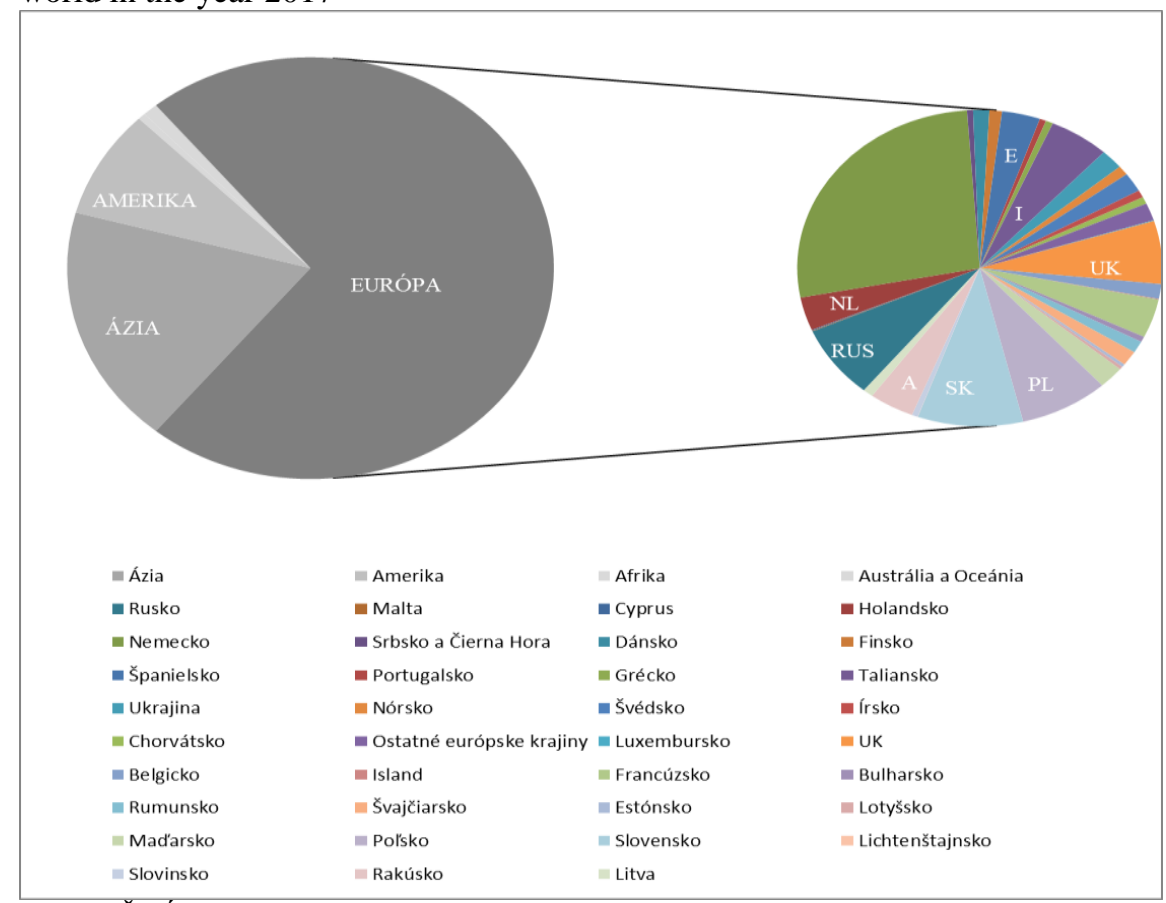

Zdroj: ČSÚ, 2018, spracovali autori 
Druhý najvýznamnejší trh pre Česko predstavuje Ázia. V rámci nej dominuje Č́na, ktorá sa okrem zaradeniu k najnavštevovanejším krajinám stáva aj jednou z najvýznamnejších zdrojových krajín cestovného ruchu Smed a Bisleva (2016) a Adamiak, Szyda a Dubownik (2018). Rastúci počet turistov prichádzajúcich do Česka pozitívne ovplyvnilo zavedenie priamych leteckých liniek medzi Prahou a čínskymi mestami Peking, Šanghaj, Čcheng-tu a Si-an. V roku 2017 sa pritom turisti z Číny v počte 489845 osôb podiel'ali 4,8 \% na návštevnosti Česka. Aj napriek poklesu Japoncov je práve Ázia druhým najvýznamnejším zdrojovým regiónom s 18,3 \% podielom. Výrazne nižšie podiely na príchod zaznamenávame v prípade turistov z Ameriky (napr. z USA navštívilo Česko v r. 2017 až 540572 turistov), Austrálie a Oceánie ako aj Afriky. Ich celkový podiel na príchodoch do Česka nepresahuje $10 \%$.

Na vyjadrenie návštevnosti Česka turistami bola použitá aj Lorenzova krivka (graf 2), ktorá prezentuje pomerne silnú koncentráciu štátov resp. vybraných častí sveta na návštevnosti Česka. Z jej analýzy je zrejmé, že polovici zdrojových štátov (50-tim \%) prislúcha iba $10 \%$ z celkového počtu ubytovaných, 75-tim \% štátov prislúcha už $30 \%$ turistov a 98-im \% štátov až 80 \% návštevníkov. Český turizmus je tak silne závislý na niekol'kých turistických zdrojových krajinách.

Graf 2: Lorenzova krivka podielu na návštevnosti Česka podl’a jednotlivých častí sveta (r. 2017)

Graph 2: Lorenz curve of the attendance share in the Czechia by individual parts of world (2017)

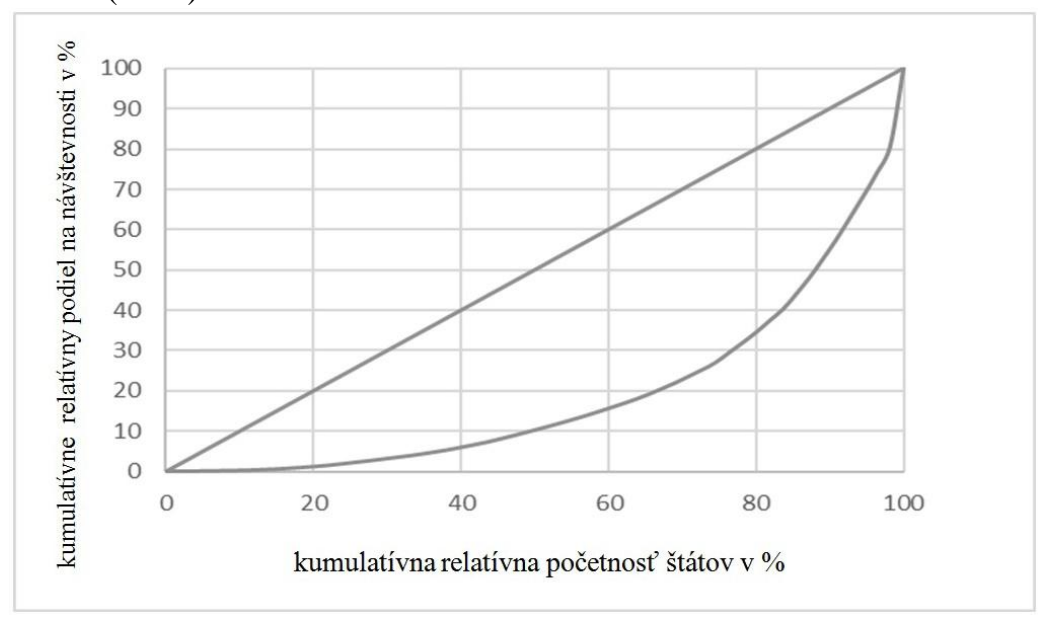

Zdroj: ČSÚ, 2018, spracovali autori

V počte prenocovaní resp. nocl'ahov vykazoval rok 2017 celkovú hodnotu 26257013 nocl'ahov. Prvotnú pozíciu, a teda aj najväčší počet prenocovaní, 
vykazovali návštevníci z Nemecka s 5760866 nocl’ahmi (tzn. 21,9 \% všetkých nocl'ahov). Po nich nasledovali návštevníci z Ruska, ktorí využili služby v podobe nocl'ahu v počte $2560872(9,8 \%)$. Na tret'om mieste v počte nocl'ahov (1 373 512) boli návštevníci zo Slovenska, ktorí predstavovali 5,2 \% podiel z celkového počtu nocl'ahov. Na d’alších pozíciách boli návštevníci z USA v počte 1314436 nocl'ahov (5,0 \%), nasledovali návštevníci z Vel'kej Británie (1 194849 - 4,6 \%), Pol'ska (1 187573 - 4,5\%), Talianska (1 067105 - 4,1\%), Ćíny (745 $352-2,8 \%)$, Holandska (754 $038-2,8 \%$ ) a desiatku uzatvára Francúzsko so 718176 nocl'ahmi $(2,7 \%)$. Viac ako dvojpercentný podiel mali na počte nocl'ahov ešte Španielsko, Izrael, Južná Kórea a Rakúsko.

Z hl'adiska priemernej dížky pobytu v Česku sa štáty v štatistickom súbore pohybujú v intervale 1,522 dňa do 5,899 dňa. Najkratší pobyt bol zaznamenaný u turistov z Č́ny $(1,522)$, Tchaj-wanu $(1,523)$ a Južnej Kórey $(1,573)$. Takéto nízke hodnoty sú spôsobené skutočnost'ou, že turisti z týchto krajín počas svojej zahraničnej dovolenky spravidla navštevujú viacero štátov, čím sa priemerná dížka pobytu v navštívenom štáte skracuje. V Česku sú ich ciel’om Praha a pamiatky UNESCO, ktorým dominuje Český Krumlov. Najdlhšie sa v Česku zdržia turisti zo Saudskej Arábie $(5,899$ dní), Ruska $(4,670)$ a Izraela $(3,729)$, čo ovplyvňuje predovšetkým ich pobyt v kúpel'ných mestách. Priemerná dížka pobytu turistu zo Slovenska dosiahla v roku 2017 hodnotu 2,014 dňa, čím sa slovenskí turisti zarad'ujú k turistom s najkratším pobytom v Česku. Je to spôsobené geografickou blízkost'ou, ktorá umožňuje navštevovat' turistické ciele v Česku napr. počas víkendu, no ako bolo uvedené vyššie s vyššou frekvenciou počas roka.

\section{Vývoj návštevnosti Česka Slovákmi}

Vývoj návštevnosti Česka občanmi Slovenska v rokoch 2000-2017 je možné rozdelit' do dvoch rozdielnych etáp. Prvou je obdobie 2000-2008, ktoré je možné zhl'adiska počtu ubytovaných i počtu prenocovaní hodnotit' ako nevyrovnané, so striedaním ich nárastu a poklesu. Maximálne hodnoty v rámci prvej etapy zaznamenávame v roku 2007 (309 255 ubytovaných, resp. 871302 prenocovaní). V tejto etape zaznamenávame najvyššiu priemernú dížku pobytu, ktorá v roku 2003 prekonala hranicu 3 dní, čo sa viac za celé sledované obdobie už nezopakovalo.

Druhá etapa začína rokom 2009 a končí rokom 2017. Ide o etapu s kontinuálne rastúcim počtom ubytovaných i počtom prenocovaním. Svoje maximálne hodnoty nadobudli v poslednom nami sledovanom roku (2017). V tomto roku dosiahol počet ubytovaných Slovákov hodnotu 681917 , počet prenocovaní bol zaznamenaný vo výške 1373512 nocl'ahov. V porovnaní s prvou etapou došlo k nárastu počtu ubytovaných o $85 \%$, v prípade počtu nocl'ahov bol nárast o $34 \%$. Túto skutočnost' mohlo pozitívne ovplyvnit' zavedenie eura na Slovensku (r. 2009), ako aj štatút Česka ako bezpečnej krajiny, čo je vo svetle 
rastúcich teroristických útokov po svete dôležitý fakt pre vol'bu miesta na dovolenku. Naopak priemerná dížka pobytu sa $\mathrm{v}$ tejto etape $\mathrm{v}$ porovnaní s prvou etapou poklesla, pričom sa pohybuje medzi hodnotami 1,97 až 2,09.

Graf 3: Vývoj návštevnosti Česka turistami zo Slovenska a priemerná dížka pobytu

Graf 3: The attendance development in Czechia by slovak tourists and average of length stay

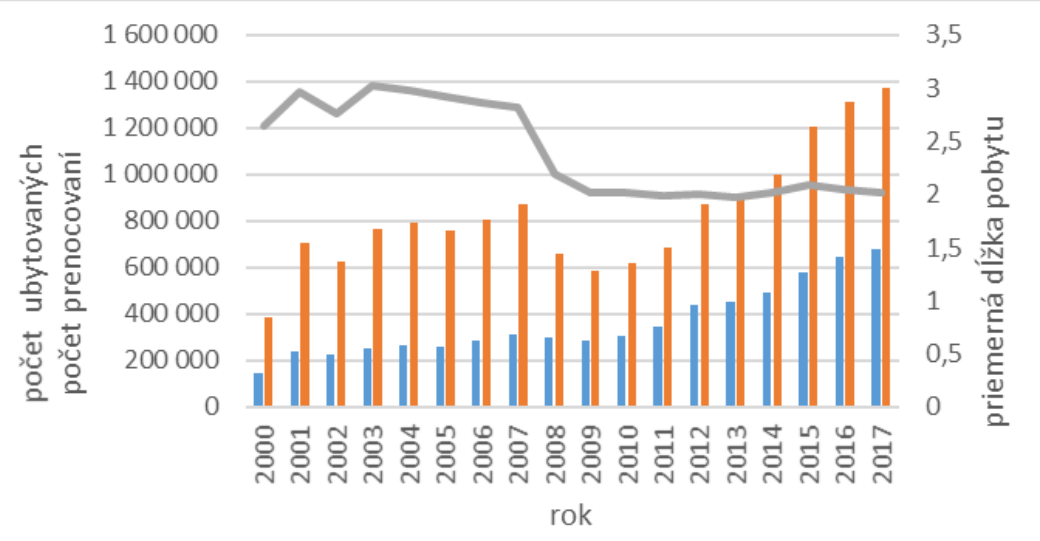

počet ubytovaných počet noclahov — priem.d. pobytu

Zdroj: ČSÚ, 2018, spracovali autori

\section{Priestorové dimenzie návštevnosti Česka turistami zo Slovenska}

Dlhodobo najvyhl'adávanejšou destináciou nielen Slovákov v Česku je hlavné mesto Praha, ktoré v roku 2017 navštívilo 287641 Slovákov. V porovnaní s predchádzajúcim rokom to bol nárast o $2,5 \%$. Z celkového podielu turistov tvorili Slováci len 4,4\%. Aj v rámci celkového počtu prenocovaní Slovákov dominuje Praha. S počtom prenocovaní 542 637, ktoré tvorili len 3,36 \%-ný podiel zo všetkých cudzincov, obsadili Slováci siedme miesto za Francúzmi. Z údajov Českého statistického úřadu (2018) vyplýva, že Praha je síce najnavštevovanejšou destináciou Slovákov v Česku, ale v rámci priemernej dížky pobytu sa v rámci krajov, radí až na predposledné, trináste miesto (1,88 dňa).

Po Prahe navštevujú Slováci najčastejšie atrakcie v krajoch bezprostredne susediacich so štátnou hranicou s Českom - v Juhomoravskom, Zlínskom a Moravskoslezskom kraji. Výraznejšie dominuje Jihomoravský kraj, ktorý v roku 2017 navštívilo 111474 turistov zo Slovenska. Slováci tvorili v tret’om cudzincami najnavštevovanejšom kraji (1. Praha, 2. Karlovarský) najpočetnejšiu skupinu. 
Tento kraj je aj v počte prenocovaní Slovákov na druhom mieste (202 392). Dížka návštevy turistov ( 1,81 dňa) patrila $\mathrm{v}$ roku $2017 \mathrm{k}$ najkratším, čo reflektuje polohu kraja vzhl'adom na Slovensko. K najnavštevovanejším ciel’om Slovákov pravdepodobne patrili zámky $\mathrm{v}$ Ledniciach, Valticiach, pamiatky krajského mesta Brna s dominantou hradu Špilberk, z prírodných pamiatok jaskyne Moravského krasu spolu s priepast'ou Macocha a i. (Institut turismu, 2018). Slováci navštevujú tento kraj aj kvôli gastroturistike, ktorá je založená najmä na kvalitnom víne.

Ostatné kraje Česka sú síce Slovákmi navštevované, ale práve dva spomínané kraje dominujú. Prahu a Jihomoravský kraj navštívilo v roku 2017 až $58,5 \%$ z turistov pochádzajúcich zo Slovenska. V rámci detailnej priestorovej diferenciácie návštevnosti (mapa 1) boli v hodnotenom roku pre Slovákov zaujímavé ešte najmä kraje Zlínsky, Moravskoslezský, Středočeský a Jihočeský.

Zlínsky kraj sa umiestnil na tret'om mieste aj v počte návštevníkov zo Slovenska (42 802) aj v počte prenocovaní (91 693). Dominancia turistov zo Slovenska s pomedzi cudzincov je v tomto kraji najvýraznejšia, tvorí až 36,04 \%ný podiel (2. Nemci 12,45\%). V centre záujmu nielen Slovákov je v tomto kraji Zoologická zahrada Zlín - Lešná, ktorá podl’a Institutu turismu (2018) bola v roku 2017 ôsmou najnavštevovanejšou atrakciou v Česku. Z ostatných zaujímavostí kraja, ktoré sú turistami navštevované, patria: Valašské muzeum v prírodě v Rožnově pod Radhoštěm, mesto Kroměřǐž so svojim barokovým zámkom a záhradami ako aj zámky Buchlovice a Buchlov a i.

Štvrtým najnavštevovanejším krajom Slovákmi je Moravskoslezský, ktorého návštevnost' má ako aj u ostatných českých krajov od roku 2012 stúpajúcu tendenciu. Celkovo 41145 turistov zo Slovenska si za ciel' svojej dovolenky vybralo práve tento kraj a strávili tu 90074 nocí. Spomedzi hraničiacich krajov so Slovenskom tu Slováci zotrvali najdlhšie (2,18 dňa). V tomto kraji Slováci tiež dominujú v rámci zahraničných turistov $(21,48 \%$ ), ale už im aj kvôli geografickej polohe sekundujú turisti z Pol'ska (39 115). Pohoria Hrubý a Nízky Jeseník ako aj Moravskoslezské Beskydy sú vyhl'adávané turistami celoročne, ked’že sa tu nachádza viacero stredísk (napr. Červenohorské sedlo blízko vrcholu Praděd v Hrubom Jeseníku či Lysá Hora v Moravskoslezských Beskydách). Z pamiatok sú hojne navštevované hrady Sovinec, Štramberk, Hukvaldy ale napr. aj Technické muzeum Tatry v Kopřivnici a i. (Institut turismu, 2018).

Naopak najmenej navštevovanými boli marginálne kraje vzhl’adom na Slovensko - Liberecký, Ústecký, Plzeňský a Karlovarský. V rámci hodnotení podl'a počtu návštevníkov ako aj podl'a počtu prenocovaní sa najlepšie umiestnil najzápadnejší kraj, ktorého nevýhodnú polohu voči Slovensku zmierňuje jeho hydropotenciál, na ktorom je založený kúpel'ný cestovných ruch (napr. Karlovy Vary, Mariánské Lázně a i.). Domnievame sa, že práve kvôli kúpel’nému cestovnému ruchu tu Slováci trávili v priemere druhú najdlhšiu dovolenku $(2,5$ dňa). Krajom, v ktorom strávili turisti najviac času, je podl'a štatistík Pardubický kraj (2,77 dňa). 
Mapa 1: Počet ubytovaných a počet nocl'ahov Slovákov v ubytovacích zriadeniach podl'a krajov Česka (r. 2017)

Map 1: Number of guests and number of overnight stays in collective accommodation establishments by country in the Czechia (2017)

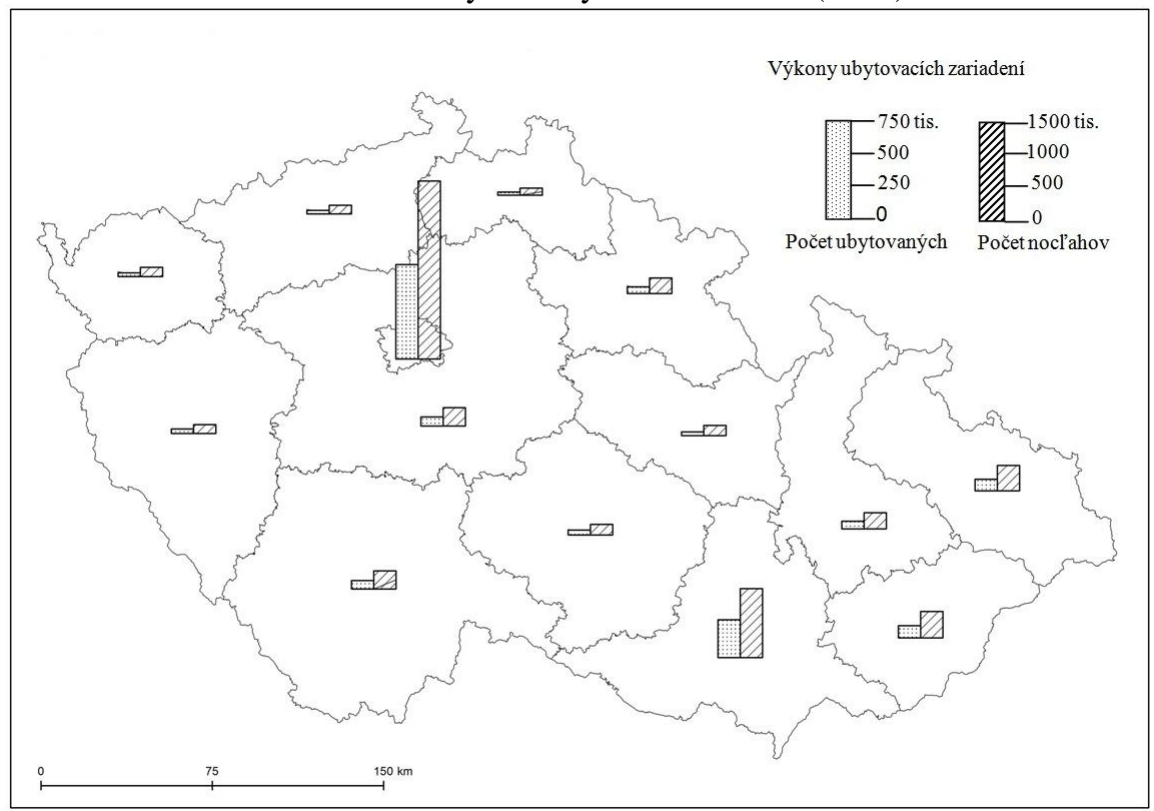

Zdroj: ČSU, 2018, spracovali autori

\section{Záver}

V článku sme sa zaoberali návštevnost’ou Česka občanmi Slovenska a ich distribúciou v priestore. Fundamentálnym zdrojom dát boli-qúdaje ČSÉ o počte ubytovaných a počte prenocovaní $\mathrm{v}$ hromadných ubytovacích zariadeniach. $\mathrm{V}$ uvedených ukazovatel'och možno Slovensko považovat' za významné zdrojové územie. V prípade počtu ubytovaných podiel Slovákov dosiahol hodnotu 6,71\%, čo je druhý najvyšší podiel hned' po ubytovaných Nemcoch (19,32\%). Podobný význam majú slovenskí turisti aj v prípade počtu nocl'ahov, kde $\mathrm{z}$ hl'adiska podielu na celkovom počte prenocovaní $(5,23 \%)$ zaujímajú tretie miesto za Nemcami $(21,94 \%)$ a Rusmi $(9,75 \%)$. Naopak, z hl'adiska priemernej dížky pobytu $(2,014$ dňa), patria turisti zo Slovenska k turistom s najkratším pobytom v Česku. Celkovo možno skonštatovat', že posudzované parametre úzko súvisia $\mathrm{s}$ geografickou blízkost'ou, ktorá umožňuje častejšie príchody Slovákov do Česka a taktiež kratšie (víkendové) pobyty. Nemožno zabudnút' aj na pozitívny efekt spoločnej existencie v spoločnom štáte a absenciu komunikačnej bariéry. 
Z hl'adiska priestorovej distribúcie slovenských turistov dominuje pochopitel'ne Praha, ako destinácia svetového turizmu s podielom 42,18\% na celkovom príchode Slovákov do Česka. Pre porovnanie Praha sa podiela 64, $59 \%$ na všetkých ubytovaniach zahraničných turistov v Česku. Okrem hlavného mesta sa návštevnost' Slovákov sústred'uje predovšetkým na prihraničné kraje, v ktorých sú Slováci dominantnými zahraničnými turistami.

\section{Pod'akovanie}

Príspevok vznikol v rámci riešenia projektu VEGA 1/0934/17 Transformácia využivania kultúrnej krajiny Slovenska za ostatných 250 rokov a predikcia jej d’alšieho vývoja.

\section{Literatúra}

ADAMIAK, CZ. - SZYDA, B. - DUBOWNIK, A. 2018. Preferencje turystów z Chin dotyczące wyboru atrakcji odwiedzanych w Europie. In Ekonomiczne problemy turystyki. ISSN 1664-0501, 2018, vol. 42, no. 2, pp. 49-58.

BERESECKÁ, J. - HUDÁKOVÁ, M. - PAPCUNOVÁ, V. 2018. Vidiecky turista budúcnosti. In Studia turistica. ISSN 1804-252X, 2018, roč. 9, č. 2, s. 6-17.

BERNÁTOVÁ, M. - VAŇOVÁ, A. 2000. Marketing pre samosprávy I. Marketing území. Banská Bystrica: UMB, 2000. 180 s. ISBN 80-8055-337-8.

BENTHEIN, B. 1997. Geographie der Erholung und des Tourismus. Gotha: Justus Perthes Verlag, 1997. 168 s. ISBN 3-623-00845-1.

ČESKÝ STATISTICKÝ ÚŘAD. 2018. [cit. 2018-09-09]. Dostupné na internete: https://www.czso.cz/csu/czso/cru_cr

DUMBROVSKÁ, V. - FIALOVÁ, D. 2016. Turistické okrsky a turistifikace v Praze: př́ípadová studie Královské cesty. In Studia turistica. ISSN 1804252X, 2016, roč. 7, č. 1, s. 6-18.

FIALOVÁ, D. - NEKOLNÝ, L. 20017. Řečí čísel cestovního ruchu. In Geografické rozhledy. ISSN 1210-3004, 2017, roč. 26, č. 3, s. 22-23.

INSTITUT TURISMU. 2018. Návštěvnost turistických cílů 2017. [cit. 2018-0909]. Dostupné na internete: http://www.czechtourism.cz/institut-turismu /marketingovy-vyzkum/infografiky/navstevnost-turistickych-cilu-2017/

KASAGRANDA, A. - RAJČÁKOVÁ, E. - VYSTOUPIL, J. 2016. Urban tourism in Slovakia - its quantification, spatial differentiation and typification. In Geographica Pannonica. ISSN 0354-8724, 2016, vol. 20, no. 2, pp. 15-113.

KASAGRANDA, A. - CÁKOCI, R. 2015. Priestorová diferenciácia a návštevnost' Slovenska občanmi Českej republiky. In Aktuálni problémy cestovního ruchu: sborník z 10. Mezinárodni konference. Jihlava: VŠPJ, 2013. ISBN 978-8088064-09-1, s. 202-214

KASAGRANDA, A. 2013. Región NUTS II Západné Slovensko ako turistická 
destinácia. In Geografické informácie. ISSN 1337-9453, roč. 17, č. 1, s. 35-43. MARCISZEWSKA, B. - STUDZIENIECKI, T. - WANAGOS, M. 2017. Tourist Arrivals in Poland - a Case Study of the Pomerania Province. In 26th International Scientific Conference on Economic and Social Development "Building Resilient Society", Zagreb. ISSN 1849-7535, pp. 648-656.

MARIOT, P. 1983. Geografia cestovného ruchu. Bratislava: VEDA, 1983. 252 s. PACHROVÁ, S. - JANOUŠKOVÁ, E. 2016. Profil návštěvníka jako významný nástroj destinačního managementu - prríkladová studie města Jihlavy. In Geografické informácie. ISSN 1337-9453, 2016, roč. 20, č. 2, s. 691-706.

PÁSKOVÁ, M. 2012. Environmentalistika cestovního ruchu. In Czech Journal of Tourism, ISSN 1805-9767 roč. 1, č. 2, s. 77-113.

SMED, K. M. - BISLEV, A. K. 2016. New Tourists at Old Destinations : Chinese tourists in Europe. In Christensen, S. F., Li, X. (eds.). Emerging Powers, Emerging Markets, Emerging Societies: Global Responses. pp. 235-255. ISBN 978-1-137- 56178-7.

STEINECKE, A. 2006. Tourismus. Eine geographische Einführung, Braunschweig: Westermann 2006. 360 p. ISBN 3141602859.

ŠAUER, M. - VYSTOUPIL, J. - KRAJÍČKOVÁ, A. 2018. Světové turistické proudy. In Sbornik príspěvki z XXI. mezinárodni kolokvium o regionálních vědách. Kurdějov: MU, 2018. ISBN 978-80-210-8970-9, s. 473-481.

VYSTOUPIL, J. - KASAGRANDA, A. - ŠAUER, M. 2016. Funkčně-prostorová typologie středisek cestovního ruchu Česka a Slovenska. In Geografický časopis. ISSN 0016-7193, 2016, roč. 68, č. 2, s. 171-192.

ZÁKON o podpore cestovného ruchu 2010. 91/2010 Z.z. 16 s. [cit. 2018-09-09]. Dostupné na internete: https://www.mindop.sk/ministerstvo-1/cestovny-ruch7/legislativa-a-koncepcne-dokumenty/legislativa/zakon-o-podpore-cestovnehoruchu.

\section{ATTENDANCE OF CZECHIA BY SLOVAK CITIZENS AND ITS SPATIAL DIMENSIONS}

\section{Summary}

In this article, we have been dealing with the attendance of Czechia by Slovak citizens and their distribution in space. The fundamental source of data were from the Czech Statistical Office - the number of guests and the number of overnight stays in collective accommodation establishments. In these indicators Slovakia can be considered as a significant source area. In terms of number of guests the share of Slovaks reached 6.71 which is the second highest share immediately after the Germans (19.32\%). Similar meaning are Slovak tourists, even if the number of overnight stays, which in terms of share in the total number of overnight stays $(5.23 \%)$ ranked third place behind the Germans $(21.94 \%)$ and 
Russians $(9.75 \%)$. On the contrary, in terms of the average length of stay $(2,014$ of day), tourists from Slovakia are tourists with the shortest stay in the Czechia. Overall, it can be concluded that the evaluated parameters are closely related to geographical proximity, which allows more frequent arrivals of Slovaks in the Czechia and also shorter (weekend) stays. Can not forget the positive effect of coexistence in the common state and the absence of communication barriers. In terms of the spatial distribution of Slovak tourists of course dominated by Prague as a world tourism destination with a share of $42.18 \%$ of the total Slovak arrival in the Czechia. For comparison Prague participates in $64.59 \%$ for accommodation of foreign tourists in the Czechia. In addition to the capital, Slovak visitors are mainly concentrated on border regions where Slovaks are the dominant foreign tourists.

Doc. RNDr. Alfred Krogmann, PhD.

RNDr. Magdaléna Nemčíková, PhD.

RNDr. Daša Oremusová, PhD.

RNDr. Lucia Šolcová, PhD.

Katedra geografie a regionálneho rozvoja FPV UKF v Nitre

Tr. A. Hlinku 1, 94974 Nitra

E-mail: akrogmann@ukf.sk,mnemcikova@ukf.sk,doremusova@ukf.sk, lsolcova@ukf.sk

RNDr. Zuzana Dvořáková Líšková, Ph.D.

Katedra regionálního managmentu

Ekonomická fakulta

Jihočeská univerzita v Českých Budějovicích

Studentská 13, 37005 České Budějovice

E-mail: zu.li@.seznam.cz 